\title{
Koronapandemia ja digiloikan opit
}

\author{
Maahan muuttaneiden naisten \\ työllistämishanke edisti \\ digitaitoja Helsingissä
}

\begin{abstract}
10
Maahan muuttaneille naisille suunnattu Women to Work -hanke osoitti, että digitaitoihin on tärkeä saada omakielistä ohjausta. Koronapandemian aikana hanke siirrettiin verkkoon, mikä vaati uudenlaisia työtapoja mutta myös harjaannutti taidoissa.
\end{abstract}

TYÖLLISTYMISTÄ PIDETÄÄN SUOMESSA yhtenä keskeisimmistä onnistuneen kotoutumisen mittareista. Julkisen sektorin työllistymispalveluilla on merkittävä rooli Suomeen muuttavien tukemisessa koulutus- ja työelämään. Tutkimuksissa (esim. Jauhola ym. 2014, 32) on havaittu, että maahan muuttaneet naiset osallistuvat miehiä useammin työvoimapoliittiseen aktivointitoimintaan, etenkin kuntoutus- ja koulutustoimintaan. Hankkeet ovatkin yksi aktiivisen sosiaali- ja työvoimapolitiikan ilmentymä Suomessa.

Yksi sellainen on maahan muuttaneiden naisten työelämäosallisuutta vuosina 2019-2021 edistänyt Women to Work, jota koordinoi Helsingin työllisyyspalvelut ja rahoitti Euroopan sosiaalirahasto (ESR). Se tarjosi Helsingin kaupungin työllisyydenhoidolle mahdollisuuden kokeilevaan kehittämiseen.

Hanke ajoittui keskelle yhteiskunnallista murrosvaihetta: keväällä 2020 alkaneen koronapandemian myötä työttömyys lisääntyi Suomessa (Tilastokeskus 2021). Samaan aikaan valmisteltiin valtakunnallisten työllisyyden kuntakokeilujen (tem.fi/tyollisyyskokeilut) käynnistämistä. Hanke herätti kiinnostuksemme digitaalisten taitojen kartoittamiseen ja digituen merkitykseen työelämään ohjaamisen kontekstissa. Osallistuimme hankkeeseen sen suunnittelusta koordinointiin ja itse toimintaan.

Maahanmuutto on elämän murrosvaiheita. Työnhaku uudessa kotimaassa voi osoittautua odotettua vaativammaksi ja pidempikestoiseksi prosessiksi (Lehtovaara 2019). Digitaidoista on tullut välttämätön kansalaistaito (esim. Codagnone \& Kluzer 2011) niin kotona kuin työelämässä. Suomessakin peruspalvelut ovat enenevässä määrin verkossa, ja digitaidot ovat välttämättömiä koulutus- ja työpaikan hakijalle. Suomalaisten enemmistö on tottunut hoitamaan viranomaisasioitaan sekä hankkimaan palveluja verkossa (Alasoini 2020, 11). 
Samanaikaisesti uusien teknologioiden mahdollisuuksia taitavasti hyödyntävien ja niiden kehityksestä pudonneiden välinen juopa, digikuilu, on laajentunut (Koiranen ym. 2016). Arviolta miljoona ihmistä Suomessa on digitaalisten palvelujen ulkopuolella tai tarvitsee niissä erityistä tukea. Eri väestöryhmät eroavat taidoissaan taustansa, kuten maaseudun ja kaupungin tai koulutuksen perusteella. Arviolta 40000 helsinkiläistä pitää digipalveluja vaikeakäyttöisinä (Tammi 2021). Digikuiluun on useita syitä, ja niitä voi olla useita samanaikaisesti. Äärimmillään ne saattavat johtaa syrjäytymiseen. Tutkijat ovatkin varoitelleet digiosattomuuden saattavan vaarantaa kansalaisten oikeusturvan (Tuusvuori 2020).

\section{DIGITAITOJEN KARTOITTAMISELLA ON MERKITYSTÄ}

Suomi on muita Pohjoismaita jäljessä maahan muuttaneiden naisten työllistämisessä. Maahan muuttaneen naisen on yli kolme kertaa vaikeampi työllistyä kuin Suomessa syntyneen naisen tai maahanmuuttajataustaisen miehen (Larja 2019). Vaikeimmin työllistyvät pakolaisstatuksella muuttaneet (Forsander 2013). Naisten työllistymiseen vaikuttavat useat tekijät, muun muassa maahanmuuton ajankohta ja- syy, lähtömaa, kansallisuus, koulutus tai ikä (Busk ym. 2016, 60-61). Rekrytointivaiheen syrjintä on yleistä (Ahmad 2019). Pitkittyvä ja haasteellinen työnhakuprosessi voi aiheuttaa odottamatonta tunnekuormaa.

Helsingin kaupungin työllisyydenhoidossa havaittiin vuonna 2018, etteivät peruspalvelut tavoittaneet riittävästi maahan muuttaneiden naisten kohderyhmää, etenkään pitkään kotona lapsia hoitaneita vanhempia, käytännössä äitejä. Näistä lähtökohdista syntyneen Women to Work -hankkeen ydintavoitteeksi nousi uudentyyppinen palvelumalli pitkään työttömänä olleiden naisten tukemiseksi kohti työelämää. Kohderyhmänä olivat arabian-, somalin- ja venäjänkieliset naiset. Lisäksi pyrittiin kouluttamaan työllisyydenhoidon ohjaushenkilöstöä ja yhteistyökumppaneita sekä lieventämään työ- ja koulutusurien sukupuolen mukaista eriytymistä. Hankekumppaneiksi ja monialaiseen ohjausryhmään kutsuttiin asiantuntijoita kolmannelta sektorilta, Helsingin yliopiston sukupuolentutkimuksen laitokselta ja yrityksistä. Mukana olivat esimerkiksi IT-alan yritys Frantic sekä Nobina ja Posti.

Kahden vuoden aikana hanketoimintaan osallistui yli 200 naista. Maahan muuttaneet naiset ovat heterogeeninen ryhmä (Larja 2019), ja myös hankkeeseen osallistujien koulutus- ja ammattitaustat sekä suomen kielen taito vaihtelivat. Ohjausta koulutukseen ja työpaikkojen hakemiseen, digitaitojen päivittämiseen sekä verkostoitumiseen tarjottiin selkosuomen lisäksi arabiaksi, somaliksi ja venäjäksi. Vaikka useat osallistujista olivat asuneet Suomessa jopa 15-20 vuotta, tiedontarve työnhakukäytännöistä, tutkintojen rinnastamisesta ja koulutuksen täydentämisestä oli suuri. Joillakin oli vain auttava suomen kielen taito, mikä tutkitusti hidastaa työllistymistä.

Pitkään työttömänä olleille siirtymä työelämään toteutuu usein osaamista tai koulutusta täydentämällä, mutta tietoa koulutuspaikoista ei saa ilman digitaitoja, ja koulutuksiin hakeudutaan verkkolomakkeilla. Helsingin työllisyyspalveluissa oli havaittu, että työnhakijalla voi iästä ja taustasta riippumatta olla sekä hyvät digitaidot että osaamisvajetta yksittäisen ohjelman käytössä, joten hankkeessa panostettiin osallistujien digitaitojen kartoittamiseen ja perustaitojen vahvistamiseen. Yhteistyötä tehtiin kaupunginkanslian viestintäosaston osallisuus- ja neuvontayksikön digiasiantuntijoiden (digituki.hel.fi) sekä Digirastihankkeen (digirasti.fi) kanssa.

Koronapandemian takia hankkeen ryhmätoiminta siirrettiin keväällä 2020 viikon varoitusajalla verkkoon. Siirtyminen lähiohjauksesta verkko-ohjaukseen lisäsi tarvetta laiteopastukseen ja lähtötaidon kartoitukseen. Ohjaajille etäohjaukseen siirtyminen toi aluksi haasteita sopivien alustojen valitsemiseen ja lukujärjestyksen sisältöjen muokkaamiseen (Launonen 2020). Asiakkaiden vaihtelevat lähtötason digitaidot vaikuttivat ohjauksen sisältöön ja ryhmäkohtaiseen muunteluun. Yhdessä ryhmässä ryhdyttiin nopeasti luomaan sähköpostitilejä, opeteltiin lataamaan sovelluksia ja avaamaan linkkejä, kun taas toisessa ryhmässä lähdettiin tutustumaan paljon haastavampiin ohjelmiin. Yksi hankeohjaaja kuvasi lähtötilannetta seuraavasti: 
"Piti huomioida 'näkymättömiä' asiakkaita, motivoida hiljaisesti istuvia ja saada heitä osallistumaan mukaan toimintaan. Onnistuin omaksua Teamsin nopeasti ja osaan ohjata asiakkaita ongelmitta (tähän saakka oli vain yksi iäkäs asiakas kenen kanssa Teamsin käyttö ei onnistunut yhtään, koska hänen kone oli niin vanha eikä tukenut Teamsin versiota). Joskus kyllä tapahtui pieniä teknisiä ongelmia, mutta yleensä työ sujui hyvin ja haasteille aina löytyy joku ratkaisu. Kun asiakas haluaa ja on aidosti motivoitunut mennä eteenpäin, yhteistyö onnistuu."

Microsoft Teams -viestintä- ja yhteistyöalustan ohella ryhmissä kerrattiin tekstinkäsittelyohjelmia ja sähköpostia työnhaun tukena: harjoiteltiin liitteiden avaamista ja lähettämistä sekä siirtymistä linkeistä uusille sivustoille. Joidenkin kanssa oli opeteltava alusta saakka verkkopankin, Reittioppaan ja Kela-sivuston käyttö. MSOffice-ohjelmia käytiin läpi, ja yleisesti haasteita tuottivat PowerPoint ja Excel.

Virtuaalista ohjausta toteutettiin omakielisissä pienryhmissä. Tarvittaessa osallistujat saivat yksilöohjausta etenkin laitteiden käyttöönotossa. Selkeä kieli ja selkokieli - sisällöltään, sanastoltaan ja rakenteeltaan yleiskielestä mukautettu kieli - sekä kuvat ja videomateriaalit havaittiin hyödyllisiksi etäohjauksessa.

\section{DIGITAIDOT LISÄÄVÄT OSALLISUUTTA}

Women to Work -hankkeessa kiinnitettiin huomiota myös laitteistojen saatavuuteen sekä tietoturvakysymyksiin. Lähes jokaisella osallistujalla oli älypuhelin, mutta ei välttämättä omaa tablettia tai kannettavaa tietokonetta. Perheenäidit tavallisesti jakoivat tietokoneen puolison tai lasten kanssa. Helsingin kattava digiohjauspiste- ja kirjastoverkosto ei tavoittanut riittävän hyvin ryhmiin osallistuvia, eikä kirjastojen ja asukastalojen mahdollisuuksia, kuten tietokoneiden ja verkon maksutonta käyttöä, välttämättä hyödynnetty. Pandemian aikana kirjastopalvelujen käyttö väheni entisestään. Ohjaajien mukaan osallistujat eivät useinkaan tienneet tarpeeksi tietoturvan perusteista, kuten omien tietojen suojaamisesta tai salasanojen vaihtamisen tärkeydestä.

Osallistujat kokivat etäohjauksen ja -neuvonnan pääosin myönteiseksi tavaksi olla mukana toiminnassa.
Haasteiden lisäksi he kertoivat etäohjauksen tuomista hyödyistä: itseopiskeluun jäi enemmän aikaa, ja digitaidot kohenivat: "Olen oppinut itse etsimään internetistä tietoa, kun aikaisemmin olin muiden avun varassa”, eräs osallistuja kertoi. Mahdollisuus osallistua täysipainoisesti ohjaukseen kotoa käsin helpotti etenkin pienten lasten vanhempia (ks. myös Melin ym. 2020, 33). Kotitehtäviä saattoi tehdä ajasta ja paikasta riippumatta. Jotkut ryhmäläiset tosin hakivat tukea perheenjäseniltään silloinkin, kun hanketyöntekijä pystyi tarjoamaan omakielistä ohjausta (ks. myös Buchert \& Kouvonen 2020). Hankkeen ohjaustyötä tekevä kuvasi ilmiötä seuraavasti:

”Tähän törmään melkein joka päivä: 'En osaa, odotan kun mies tulee töistä [tai lapsi tulee koulusta] ja auttaa.' Heikon suomen kielen taidon vuoksi yleensä asiakkaat eivät hae itse apua kaupungin palveluista, koska pelkäävät etteivät ymmärrä sisältöä ja asiaa.”

Laitteistojen ja ohjelmien saavutettavuuden ohella selkeä- ja omakielinen, matalalla kynnyksellä saatava opastus oli välttämätöntä. Myönteisellä ja kannustavalla ohjausotteella oli merkitystä, sillä aikuisoppijan ei aina ollut helppoa pyytää apua digitaitoihin. Puolison ja perheen myönteinen suhtautuminen tuki uuden oppimista, ja hankkeessa keskusteltiinkin parisuhteen ja perheen kannustuksen merkityksestä aikuiskoulutukseen tai työelämään siirtymisvaiheessa. Etäosallistuminen mahdollisti keskustelun läsnätapaamisia paremmin, koska usein osallistujat kokivat, että sensitiiviseksi koetusta aiheesta oli helpompaa puhua verkkovälitteisesti, tarvittaessa ilman kameraa.

\section{VERKOSTOITUMINEN VERKOSSA TUKEE TYÖNHAKUA}

Työnhaussa suosittelijat ovat tärkeitä, eikä ilman sosiaalisia ja ammatillisia verkostoja välttämättä saa edes tietoa työpaikoista. Useimmat maahan muuttaneet naiset ovat tulleet Suomeen perhesyistä (Larja 2019), jolloin koulutus- tai työpaikkaa, saati ammatillisia verkostoja ei välttämättä ole valmiina. Tutkimukset osoittavat, että silläkin on väliä, millaisia verkostot ovat (esim. Fossland 2013). Koronan myötä 
ammatillinen verkostoituminen ja rekrytointitapahtumat ovat siirtyneet verkkoon. Suurin osa verkon ja sosiaalisen median työnhakualustoista, kuten LinkedIn tai Twitter, Facebook, operoi suomeksi tai englanniksi, mikä sulkee ulos ne, jotka eivät näitä kieliä vielä osaa. Ilman digitaitoja ei liioin ole pääsyä verkon tietolähteille. Tästä syystä Women to Work -hankkeen omakieliset ohjaajat kannustivat toimintaan osallistuvia käyttämään sosiaalista mediaa verkostoitumisen sekä koulutukseen ja työelämään hakeutumisen tukena. Hankkeen Facebook-ryhmässä oli mahdollisuus keskustella ja verkostoitua suomen lisäksi arabian, somalin ja venäjän kielillä.

Julkiset työvoimapalvelut ovat merkittäviä toimijoita maahan muuttaneiden koulutukseen ja työelämään ohjaamisessa. Pääministeri Sanna Marinin (sd) hallitusohjelmaan sisältyy digitaalisten palvelujen saavutettavuuden edistäminen. Samaan asiaan pureudutaan Digi arkeen -neuvottelukunnassa (vm.fi/digiarkeen-neuvottelukunta). Digi- ja väestötietoviraston (dvv.fi/henkiloasiakkaat) koordinoimat alueellisen digitaalisen tuen hankkeet puolestaan rakentavat paikallista yhteistyöverkostoa ja tarjoavat apua digitukityötä tekeville tahoille. Helsingin kaupunki järjestää normaalioloissa digineuvontaa yli 150 toimipisteessä. Koronan takia kaupunki aloitti keväällä 2020 digituen etäopastuksen, jossa palvelua saa puhelimitse, chatissa ja verkkolomakkeella. Keväällä 2021 käynnistettiin koteihin jalkautuva digitukipalvelu.

Korona-aika on tuonut mahdollisuuksia ajasta ja paikasta riippumattomaan työskentelyyn ja opiskeluun, mutta tämä vaatii asianmukaiset työvälineet ja kaikille saavutettavat ohjelmat ja verkkosivustot (Melin ym. 2020, 33). Etätuen käyttö voi olla haastavaa, jos ei aiemmin ole käyttänyt tietotekniikkaa. Women to Work -hankkeessa havaittiin, että omakielisellä, selkokielellä tuetulla ohjauksella tuetaan tehokkaasti pitkään työttömänä olleita maahan muuttaneita naisia työelämään sekä kartoitetaan ja kohennetaan työnhakijoiden digitaitoja. Monikielisiä palveluita on kokeiltu muillakin kaupungin toimialoilla, esimerkiksi kasvatuksessa ja koulutuksessa. Yliopistonlehtori Terhi Ainiala (2021) korostaa, että selkokielen käyttö kaupungin palveluista viestittäessä edistää yhdenvertaisuutta ja saavutettavuutta. Ei ole myöskään yhdentekevää, kuka ohjelmia, sovelluksia ja oppimisympäristöjä suunnittelee. Jotta digitaalinen osallisuus toteutuisi, palveluiden käyttäjät tulee osallistaa palvelujen kehittämiseen jo suunnitteluvaiheessa.

\section{LOPUKSI}

Women to Work -hanke päättyi heinäkuussa 2021, mutta sen toimintamallien jalkauttamista jatketaan. Euroopan sosiaalirahaston (ESR) myöntämä hankerahoitus tarjosi Helsingin kaupungin työllisyydenhoidolle mahdollisuuden kokeilla ja kehittää uudentyyppistä palveluohjausta. Kehittämishankkeet ovat tehokkaita työvälineitä, joilla pystytään reagoimaan nopeasti toimintaympäristön muutoksiin.

Digitaidot on kansalaistaito, joka helpottaa elämää, antaa lisää sisältöä ja kasvattaa henkilökohtaista vapautta (Rentola \& Viitanen 2020). Maahan muuttaneiden naisten tapauksessa tämä on erityisen tärkeää, koska heitä työllistävät alat Suomessa vaativat hyvät digitaidot.

Sukupuolisen eriytymisen vähentämiseksi tehdään hankkeissa jatkuvasti työtä. Maahan muuttaneiden naisten työllistämisen tukemiseen kannattaa panostaa myös tulevaisuudessa. Naisilla heikko työmarkkinaasema periytyy eli vaikuttaa perheen lapsiin, erityisesti tyttäriin (Kurronen 2021). Monikielinen digiohjaus edistää naisten kotoutumista ratkaisevasti.

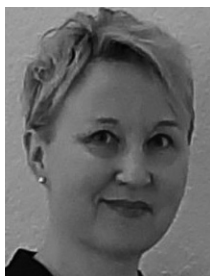

HEIDI LEHTOVAARA

FM, tohtorikoulutettava yhteiskuntatieteellinen tiedekunta Tampereen yliopisto esihenkilö maahanmuuttaneiden palvelut Helsingin työllisyyspalvelut

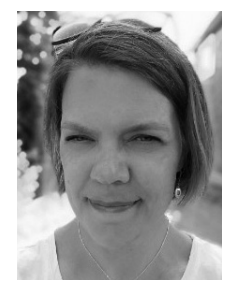

TANJA NAMROOD

FM, arabian kieli ja islamilainen kulttuuri sairaanhoitaja, NTM projektisuunnittelija Women to Work -hanke (2019-2021) työkykykoordinaattori Tunnista, ennaltaehkäise, ohjaa ja tue moniammatillisesti osatyökykyisiä (TEOT) -hanke Keravan kaupunki 
Ahmad, A. (2019). Kokeellinen tutkimus etniseen alkuperään perustuvasta syrjinnästä suomalaisilla työmarkkinoilla. Teoksessa Kotoutumisen kokonaiskatsaus 2019: Tutkimusartikkeleita kotoutumisesta. TEM oppaat ja muut julkaisut 2019:10. Helsinki: Työ- ja elinkeinoministeriö.

Ainiala, T. (2021). Selkokieli on tärkeä väline Suomeen muuttajalle. Helsingin Sanomat 23.8.2021.

Alasoini, T. (2020). Askelmerkkejä työelämän todelliseen digiloikkaan. Työpoliittinen aikakauskirja 1/2019.

Buchert, U. \& Kouvonen, A. (2020). Digitalisaatio jättää haavoittuvimpia ihmisiä ilman lakisääteisiä palveluja. Yliopistolehti 8/2020. https://www.helsinki.fi/fi/ uutiset/hyvinvointiyhteiskunta/digitalisaatio-jattaahaavoittuvimpia-ihmisia-ilman-lakisaateisia-palveluja

Busk, H., Jauhiainen, S., Kekäläinen, A., Nivalainen, S. \& Tähtinen, T. (2016). Maahanmuuttajat työmarkkinoilla - tutkimus eri vuosina Suomeen muuttaneiden työurista. Eläketurvakeskuksen tutkimuksia. https:// www.etk.fi/ wp-content/uploads/Maahanmuuttajat_ tyomarkkinoilla.pdf

Codagnone, C. \& S. Kluzer (2011). ICT for the social and economic integration of migrants into Europe. JRC Scientific and Technical Reports.

Fossland, T. (2013). Crossing borders - getting work: Skilled migrants' gendered labour market participation in Norway. Norwegian Journal of Geography, 67(5): 276-283. https://doi.org/10.1080/ 00291951.2013 .847854$.

Forsander, A. (2013). Maahanmuuttajien sijoittuminen työelämään. Teoksessa T. Martikainen, P. Saukkonen \& M. Säävälä (toim.) Muuttajat. Kansainvälinen muuttoliike ja suomalainen yhteiskunta. Helsinki: Gaudeamus.

Jauhola L., Oosi, O. \& Horelli, L. (2014). Sukupuolinäkökulma työ- ja elinkeinotoimistojen palveluihin. Työ- ja elinkeinoministeriön julkaisuja. Työ ja yrittäjyys 52/2014. https://docplayer. fi/4374907-Sukupuolinakokulma-tyo-jaelinkeinotoimistojen-palveluihin.html

Kanninen, O. \& Virkola, T. (2021). Rekrytointisyrjintä ja sen vastaiset keinot. Valtioneuvoston selvitys- ja tutkimustoiminnan julkaisusarja 2021:27. Helsinki: Valtioneuvoston kanslia.
Koiranen, I., Räsänen, P. \& Södergård, C. (2016). Mitä digitalisaatio on tarkoittanut kansalaisen näkökulmasta? Talous \& Yhteiskunta 45(3): 24-29.

Launonen, T. (2020). Maahan muuttaneet naiset tekivät digiloikan - työnhakuryhmä siirtyivät verkkoon. https://kotouttaminen.fi/blogi/-/blogs/maahanmuuttaneet-naiset-tekivat-digiloikan-tyonhakuryhmatsiirtyivat-verkkoon

Larja, L. (2019). Maahanmuuttajanaiset työmarkkinoilla ja työmarkkinoiden ulkopuolella. Teoksessa Kazi ym. (toim.) Kotoutumisen kokonaiskatsaus 2019: Tutkimusartikkeleita kotoutumisesta. TEM oppaat ja muut julkaisut 2019:10. Helsinki: Työ- ja elinkeinoministeriö.

Lehtovaara, H. (2019). "Toki mä voin saada töitä": Korkeasti koulutettujen maahan muuttaneiden naisten odotukset ja kokemukset työnhakuprosessista Suomessa. Pro gradu. Helsingin yliopisto. https://helda. helsinki.fi/handle/10138/302974

Melin, H., Turja, T. \& Krutova, O. (2020). Työelämän uusi normaali? Työpoliittinen aikakauskirja 3/2020.

Rentola, J. \& Viitanen, J. (2020). Digituen antaminen on liikaa vapaaehtoisten harteilla. Helsingin Sanomat 16.11.2020.

Tammi, A. (2021). Asiantuntijahaastattelu 31.3.2021. Kaupunginkanslian osallisuus- ja neuvontayksikkö.

Tuusvuori, A. (2020). Digitalisaatio jättää haavoittuvimpia inmisiä ilman lakisääteisiä palveluja. Yliopistolehti 23.10.2020. https://www.helsinki.fi/fi/ uutiset/hyvinvointiyhteiskunta/digitalisaatiojattaa-haavoittuvimpia-ihmisia-ilman-lakisaateisiapalveluja?fbclid=IwAR12sPH4KqF_dVJqfAEOrPbvCz_ M8U4Uz_jQX0ZAhGsPWOWThFqm0jIKehE

Valtiovarainministeriö (2020). Kaikkien osallisuus ja hyvinvointi ovat keskeisiä digitaalisessa yhteiskunnassa. VM:n verkkosivut. https://vm.fi/-/kaikkien-osallisuus-jahyvinvointi-ovat-keskeisia-digitaalisessa-yhteiskunnassa 